\title{
Intractable Iron Deficiency after Gastric Bypass Surgery
}

\author{
Rui Ribeiro*, Anabela Guerra \\ Surgery Treatment Unit for Obesity and Endocrine Diseases, Curry Cabral Hospital, Portugal
}

Submission: May 10,2017; Published: June 07, 2017

*Corresponding author: Rui Ribeiro, Surgery Treatment Unit for Obesity and Diseases Endoccrins, Coordinator, Senior surgeon, Curry Cabral Hospital, Lisbon Hospital Center, Central, EPE, Lisbon, Portugal, Tel: 97333970898; Email:ruijsribeiro@gmail.com

Summary

We present the clinical case of a woman, 53 years old, submitted to a revisional gastric bypass after a failed gastric band, who presents a so severe iron deficiency that, although continuous oral supplementation still needed transfusional iron therapy every 2-3 weeks! After two years with no improvement, a new surgical approach was decided and a conversion from gastric bypass to sleeve gastrectomy was decided and performed. Finally, one year after this operation, anemia control and normal iron plasmatic levels are finally achieved.

\section{Introduction}

Gastric bypass is one of the most important surgical tools in bariatric surgery with good outcomes considering weight regain and co-morbidities control. Bariatric surgery appears efficacious compared to standard care in reducing BMI [1]. Such a phenomenon is related to diminished alimentary intake and reduced absorption of some mineral and vitamins because of an excluded duodenal and proximal jejunum transit [2].

Iron deficiency is one of the consequences of different bariatric surgeries, namely after a gastric bypass [3]. In most cases, alimentary adaptations accordingly to dietitian counseling, multivitamin and oral iron supplementation are enough to achieve good levels of plasmatic iron [4].

Sometimes, transfusional iron therapy is necessary for a certain period of time and revisional surgery may be considered when medical treatment is not effective [5].

\section{Case report}

A 53 years old woman, nurse, with morbid obesity, was submitted to gastric banding when she was 42 (2004). At that time the anthropometric parameters were: height-1,58m, weight-136 kg, BMI-54, $6 \mathrm{Kg} / \mathrm{m}^{2}$. Her comorbidities were: Sjogren syndrome, disautonomic bradicardia and hypotension, depression, asthma. She lost until $76 \mathrm{~kg}$ and maintained such a weight for five years.

Two years after the surgery, she suffered an embolic stroke due to foramen oval patency and was submitted to cardiac catheterization to close the defect. In 2011, seven years after gastric banding, she developed Gastro-esophageal reflux disease (GERD) symptoms and dysphagia; the gastric band was deflated and weight regain occurred until $105 \mathrm{~kg}$, BMI $42 \mathrm{Kg} / \mathrm{m}^{2}$. An upper digestive series study showed up a slippage (gastric prolapse) and an esophageal dilatation.

In November 2011, a new laparoscopy was performed, her band removed and a Roux en Y gastric bypass constructed, with no events in the post operative period. She took weight off until $80 \mathrm{~kg}$.

After a few months, maintaining dietetic counseling and continuous oral multivitamin supplementation, she presented a severe iron deficiency (Fe $10 \mathrm{mcg} / \mathrm{dl}$ and Ferritin $3 \mathrm{ng} / \mathrm{ml}$ ) and a symptomatic anemia with hemoglobin values varying between 9 and $11 \mathrm{~g} / \mathrm{dl}$, under transfusional iron therapy every 2-3 weeks.

She had also vitamin D, calcium and magnesium deficiency and a Parathormone elevation.

After two years of such a clinical status, she was proposed for a conversion of her RY gastric bypass to vertical calibrated gastrectomy (sleeve). The contrast study, held at that time, showed thickening of esophageal folds at lower third, normal progression of the contrast at the esophago-gastric transition and gastro-jejunal anastomosis, with herniation of small amount of the gastric pouch into the esophageal hiatus.

In February 2015 she had regained weight until $93 \mathrm{~kg}$ with a corresponding BMI of $36,8 \mathrm{Kg} / \mathrm{m}^{2}$. At that time, the patient was 
again submitted to surgery to perform conversion of RY gastric bypass to sleeve gastrectomy and hiatoplasty, with no adverse incidents.

A new contrast study was done one month later, showing no hiatal hernia evidence, a tubular stomach with a narrowing in the body $2 \mathrm{~cm}$ long and about $1 \mathrm{~cm}$ wide, fast progression of contrast media, slight duodeno-gastric reflux and spontaneous esophago-gastric reflux in orthostatic position and under provocative maneuvers.

In the present, her weight is $71 \mathrm{~kg}$ and the BMI is $28,5 \mathrm{Kg} /$ $\mathrm{m}^{2}$. She never has had this weight before. The unique complains are now a slight esophago-gastric reflux easily controlled with proton inhibitors bomb and some light obstipation. She is under oral multivitamin supplementation with Fitforme WLS Forte ${ }^{\circledR}$, plasmatic iron levels in the normal range, no deficiency of calcium or vitamin D and a normal PTH value.

She's happy, feeling plenty of energy, optimistic about the future! And so we are too!

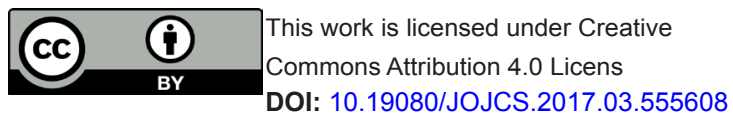

\section{References}

1. R Padwal, S Klarenbach, N Wiebe, D Birch, S Karmali, AM Sharma et al. (2011) Bariatric surgery: a systematic review and network metaanalysis of randomized trials. Obesity reviews 12(8): 602-621.

2. Katrina Parker, Paul O'Brien, Leah Brennan (2014) Measurement of Disordered Eating Following Bariatric Surgery: a Systematic Review of the Literature. Obes Surg 24(6): 945-953.

3. Jeffrey IM, Adrienne Youdim, Daniel B Jones, W Timothy, Daniel L, et al. (2013) Clinical Practice Guidelines for the Perioperative Nutritional, Metabolic, and Nonsurgical Support of the Bariatric Surgery Patient-2013 Update: Cosponsored by American Association of Clinical Endocrinologists, The Obesity Society, and American Society for Metabolic \& Bariatric Surgery. Endocrine practice 21(1): $1-27$.

4. Carina, Andriatta Blume (2012) Nutritional Profile of Patients Before and After Roux-en-Y Gastric Bypass: 3-Year Follow-up. Obes Surg 22(11): 1676-1685.

5. Chung-Yen Chen, Lee WJ, Lee HM, Chen JC, Ser KH, et al. (2016) Laparoscopic Conversion of Gastric Bypass Complication to Sleeve Gastrectomy: Technique and Early Results. Obes Surg 26(9): 20142021.

\section{Your next submission with Juniper Publishers} will reach you the below assets

- Quality Editorial service

- Swift Peer Review

- Reprints availability

- E-prints Service

- Manuscript Podcast for convenient understanding

- Global attainment for your research

- Manuscript accessibility in different formats ( Pdf, E-pub, Full Text, Audio)

- Unceasing customer service

Track the below URL for one-step submission https://juniperpublishers.com/online-submission.php 